\title{
ROOT KNOT NEMATODE INFECTIONS PROMOTED BY AGRICULTURAL PRACTICE MODIFICATIONS IN VIETNAM AND THE IMPACTS ON RICE PRODUCTION
}

\author{
Nguyen Thi Hue ${ }^{1, *}$, Anne-Sophie Masson ${ }^{1,2,3}$, Lionel Moulin ${ }^{3}$, \\ Trinh Quang Phap ${ }^{4,5}$, Ha Viet Cuong ${ }^{6}$, Stéphane Bellafiore ${ }^{1,3}$ \\ ${ }^{1}$ LMI RICE2, Agriculture Genetic Institute (AGI), University of \\ Science and Technology of Hanoi (USTH), Ha Noi, Vietnam \\ ${ }^{2}$ University of Montpellier, Montpellier, France \\ ${ }^{3}$ IRD, CIRAD, University of Montpellier, IPME, Montpellier, France \\ ${ }^{4}$ Institute of Ecology and Biology resources, VAST, Vietnam \\ ${ }^{5}$ Graduate University of Science and Technology, VAST, Vietnam \\ ${ }^{6}$ Faculty of Agronomy, Vietnam National University of Agriculture, Ha Noi, Vietnam
}

Received 5 May 2020, accepted 31 July 2020

\begin{abstract}
A survey conducted on newly cultivated lowland rice fields by direct seeding method in Hai Duong Province, Viet Nam, in March 2017 revealed high devastation of the field. In these fields, farmers used an annual crop rotation cycle of rice-scallion-rice. Investigations on the devastated fields revealed that the chemical and physical soil properties were appropriate for rice cultivation. On the other hand, observations done on the root systems showed that the dead plants have symptomatic root galls suggesting the presence of plant parasitic nematodes. Sequencing of the internal transcribed spacer (ITS) region of the rDNA genes of the nematodes showed that the root nematodes extracted from the infested fields belonged to Meloidogyne graminicola. The reproductive factor of the isolated M. graminicola population on the IR64 rice variety (Oryza sativa indica) was normal, suggesting that the impact of this plant pest was not due to the emergence of an unusual virulent population. The combination of the three factors (wrong cropping choice for rotation, using rice variety susceptible to $M$. graminicola and direct seeding) were obviously promoting the nematode infection and its high proliferation in the surveyed fields. Meloidogyne graminicola could parasitize and propagate in scallions of Vietnam. Since this plant is annually cultivated on a paddy field for crop rotation, preventive measures or alternative plant for crop rottion is necessary.
\end{abstract}

Keywords: Meloidogyne graminicola, cropping sequence, rice, scallions, virulent.

Citation: Nguyen T. H., Masson A. S., Moulin L., Trinh Q. P., Ha V. C., Bellafiore S., 2020. Root knot nematode infections promoted by agricultural practice modifications in Vietnam and the impacts on rice production. Academia Journal of Biology, 42(3): 31-42. https://doi.org/10.15625/2615-9023/v42n3.15036.

*Corresponding author email: huebiovfu@gmail.com

C2020 Vietnam Academy of Science and Technology (VAST) 


\section{INTRODUCTION}

Rice is the most cultivated cereal and the most important staple food in Vietnam. According to FAO statistics, Vietnam is ranked at the $5^{\text {th }}$ among rice producing countries in terms of weights, after China, India, Indonesia and Bangladesh, with 42.8 million tonnes of paddy rice produced in 2017 (FAOSTAT, 2017). However, Vietnam ranks $26^{\text {th }}$ among rice producing countries in terms of yields, at $55,476 \mathrm{hg} / \mathrm{ha}$ in 2017 . Annually, pests such as plant parasitic nematodes (PPNs) are known to be responsible for agricultural losses of more than \$US 80 billion (Nicol et al., 2011). they are particularly detrimental to rice (Mantelin et al., 2017). The most damaging PPN for rice is Meloidogyne graminicola (M. graminicola). This root-knot nematode (RKN) has a large host range and geographical distribution (Mantelin et al., 2017). RKNs are telluric obligate plant parasites that induce gall formation in the infected roots to facilitate female development (Bridge and Page, 1982). The sedentary female feeds on the plant cells in the root galls where they hijack the plant's metabolism making it weaker with a small root system and consequently severely compromise rice yields (Bridge Page, 1982).

In Vietnam, rice is cultivated in almost all provinces with two intensive production regions being the Red River Delta in the North and the Mekong Delta in the South. In the Red River Delta, farmers routinely have two rice crop productions a year with occasionally one crop rotation during the offseason (e.g. scallion, potato, sweet potato, pumpkin, corn, sesame (Nguyen, 2009; Pham et al., 2013). Due to the fast socio-economic changes in Vietnam, including urban migration and reduction of agricultural workforce (World Bank, 2019), in some provinces, farmers have recently stopped doing the traditional timeconsuming transplanting and shifted to direct seedling practices. This practice saves time but is unfortunately accompanied by unwanted side effects like increased impacts by parasites such as PPN (De Waele \& Elsen, 2007). Previous studies in Vietnam only noted the presence of $M$. graminicola species in paddy rice
(Nguyen \& Nguyen, 2000; Bellafiore et al., 2015), but damage assessment of $M$. graminicola in fields have not been conducted. In March 2017, our survey in Hai Duong Province revealed that several rice fields were highly devastated. Farmers were presented with the hypothesis that a nematode attack was compromising their rice production.

In this study, we analyzed the reasons that could explain the unusual proliferation of PPN and its observed impacts on rice in Hai Duong Province, Vietnam. Three main hypotheses were tested: (i) A pest (nematode) highly aggressive to rice was emerging, (ii) Farmers used rice genotypes highly susceptible to nematode infections, and (iii) Modification of the farmer practices lead to the proliferation of the pest.

\section{MATERIALS AND METHODS}

\section{Field description, plant and soil sampling}

The survey was conducted on the $11^{\text {th }}$ March, 2017 in Nam Sach district, Hai Duong Province $\left(21^{\circ} 00^{\prime} 51.1^{\prime \prime} \mathrm{N}\right.$ and 106 $\left.19^{\circ} 33.0^{\prime \prime} \mathrm{E}\right)$ (Figs. 1a, 1b). The Red River Delta of Northern Vietnam has a tropical monsoon climate. The three rice fields, where the survey was carried out, are inside a ten-ha area of land with three crops rotation per year: two rice and one scallion crop production cycle. For a decade, farmers have been growing scallion in the winter before cultivating two cycles of rice in spring and summer. Chemical fertilizers have been mainly used (from 8 to $8.5 \times 100 \mathrm{~kg}$ $\mathrm{NPK} / \mathrm{ha} /$ rice crop, and from 1 to $1.5 \mathrm{P}_{2} \mathrm{O}_{5} \times$ $1,000 \mathrm{~kg}+300 \mathrm{~kg}$ Urea $+200 \mathrm{KCl} / \mathrm{ha} /$ scallion crop). Chemical pesticides were routinely applied to control plant pathogens whenever the epiphytotic of plants appeared in the field. For the first rice cropping cycle in 2017, 15 days after ploughing, the farmer planted the rice variety $\mathrm{Bac}$ Thom $\mathrm{N}^{\circ} 7$ (Oryza sativa indica) by direct seeding. In the spring of 2017, due to unusual water scarcity, the fields were exposed to a drought stress for up to 20 days. Nearly four weeks after direct seeding, almost all seedlings died, presenting leaf chlorosis and small root systems with swelling galls Fig. 1c). 


\section{Plants and soil sampling}

Three fields, 3,000 $\mathrm{m}^{2}$ each, were surveyed from the rice cultivated area (Fig. 1b). Each field was subdivided in four plots of $100 \mathrm{~m}^{2}$ each. 50 plants were randomly collected from each plot, i.e. a total of 600 plants were analyzed. In addition, a composite soil sample was taken per plot for physical and chemical properties analysis Each plant or soil sample was kept in a separate and labeled plastic bag at $4{ }^{\circ} \mathrm{C}$ until laboratory analysis. Plant samples were analyzed at LMI RICE2 (Ha Noi, Vietnam), and soil properties were analyzed at the Soil Science Department, Faculty of Land Management in the Vietnam National University of Agriculture (VNUA, Ha Noi, Vietnam).
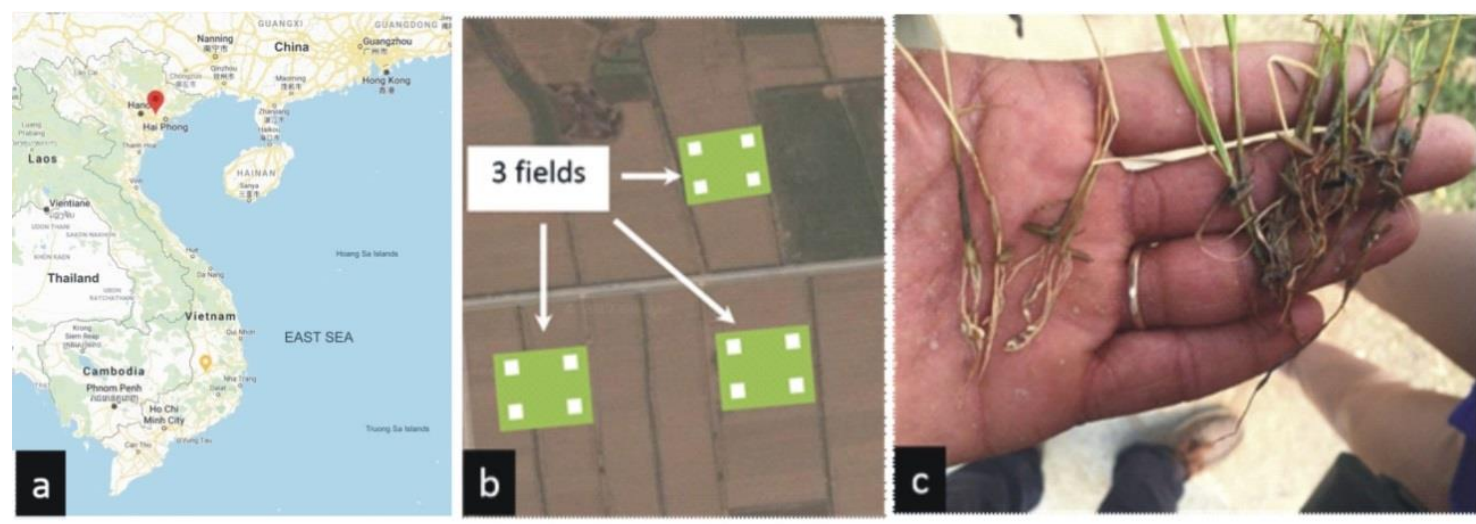

Figure 1. Rice fields of Hai Duong Province in Vietnam (a), location of the surveyed fields in Vietnam; (b) the three fields (in green) and the four plots (white) for each field where soil and plant samples were collected; (c) infested plants (left) with small terminal root galls and chlorosis leaves

\section{Nematode extraction}

Plants were picked up and scanned carefully for the presence of galls characteristic of RKN infection. The nematode extraction was carried out using the hypochlorite extraction method and a blender (McClure et al., 1973) with minor modifications (Bellafiore et al., 2015). Briefly, root galls collected in the field were carefully washed with tap water to remove soil then put in a $150 \mathrm{ml}$ beaker containing $0.5 \%$ hypochlorite solution for two minutes before manually breaking the galls to extract nematode eggs and juveniles (J2). The mixture was then filtered through an $80 \mu \mathrm{m}$ sieve to remove plant root tissues. Eggs and J2 were recovered on a second $25 \mu \mathrm{m}$ sieve, rinsed several times with tap water in order to remove the hypochlorite solution. Eggs and J2 were placed on a strainer covered by two damp Kimwipe tissues on a $50 \mathrm{ml}$ beaker filled with sterile $\mathrm{ddH}_{2} \mathrm{O}$. After being kept for two days in the dark at room temperature, nematodes were collected for further experiments.

\section{Nematode identification}

Firstly, rice root galls extracted from fields were stained with acid fuchsin (Byrd et al. 1983) to confirm the presence of PPN. Secondly, under a stereomicroscope, freshly extracted $\mathrm{J} 2$ were observed and individually collected. Nematodes were fixed in TAF (91 $\mathrm{ml} \mathrm{H}_{2} \mathrm{O} ; 7 \mathrm{ml}$ of $40 \%$ formalin; $2 \mathrm{ml}$ of triethanolamine) and transferred to anhydrous glycerine to make permanent slides following Seinhorst (1959). Perineal patterns of the swollen females were cut, cleaned, and mounted in glycerine following Hartman \& Sasser (1985).

Twenty single $\mathrm{J} 2$ were picked up in $10 \mu \mathrm{l}$ of $\mathrm{ddH}_{2} \mathrm{O}$ and transferred individually in twenty PCR tubes. $10 \mu 1$ of $2 \mathrm{X}$ DNA lysis buffer was then added to each PCR tube to 
proceed DNA extraction by a proteinase $\mathrm{K}$ method as described by Bellafiore et al. (2015). Primers rDNA2 (5'TTGATTACGTCCCTGCCCTTT- 3') and rDNA $1.58 \mathrm{~s} \quad\left(5^{\prime}\right.$ ACGAGCCCGAGTGATCCACCG-3') were used to amplify the internal transcribed spacer (ITS) region of the rDNA gene (Vrain et al., 1992). PCR was performed following Bellafiore et al. (2015) with 35 PCR cycles of $95{ }^{\circ} \mathrm{C}$ for 30 seconds, $54{ }^{\circ} \mathrm{C}$ for $30 \mathrm{sec}$ and $72{ }^{\circ} \mathrm{C}$ for $1 \mathrm{~min}$ followed by one step at $72^{\circ} \mathrm{C}$ for $10 \mathrm{~min}$. Amplicons were gel-purified and seven samples having good result after purification were directly sent for sequencing (Macrogen, South Korea) using primer rDNA2. ITS sequences were blasted against NCBI's nucleotide-collection (nr/nt) database, aligned with reference accession numbers $M$. graminicola MgVN18 KF250488, $M$. graminicola MgVN13 KF250481; $M$. graminicola HM623442.1; $M$. naasi, JN157863; $M$. arenaria, AF387092; $M$. incognita, KC464469; M. javanica AY438555; M. hapla LC030362.1 and LC030359; Hirschmanniella oryzae, EU722286 and Globodera rostochiensis GQ294519.1 using MUSCLE v3.8.31 (Edgar, 2004) and cleaned with GBLOCKS (Castresana, 2000). The phylogenetic tree using the ITS sequence of Meloidogyne isolated at Hai Duong and other nematode species was constructed using Maximum Likelihood (ML) analysis in MEGA 6 software with 1000 bootstrap replications.

\section{Reproduction factor and virulence test}

The scallion cultivar and IR64 cultivar (Oryza sativa) were grown to assess their susceptibility to $M$. graminicola under controlled conditions $\left(28^{\circ} \mathrm{C}, 16\right.$ hours light- 8 hours dark). Before transplanting, the scallion bulbs were treated for $10 \mathrm{~min}$ in $1 \%$ aqueous sodium hypochlorite solution before being rinsed several times with tap water. Scallion were grown in $20 \times 20 \mathrm{~cm}$ pots previously filled with autoclaved sandy soil made of $50 \%$ sand and $50 \%$ potting soil and watered every three days in order to conserve a nonsaturated soil. Two weeks after planting, each plant was inoculated with $200 \mathrm{~J} 2$ (initial population "Pi"). Concurrently, 10 days old IR64 seedlings cultivated in small columns containing autoclaved sand were inoculated with 200 freshly hatched J2s. At 27 days, post-inoculation (dpi) roots were collected, one gram of root was stained with acid fuchsin (Byrd et al., 1983).

Nematode in rice and scallion roots were extracted according to the method described above. Under stereomicroscope, for each root system, eggs and nematodes were counted and the sum of eggs and J2 gave the final population density "Pf". The reproductive factor ( $\mathrm{Rf}$ ) was calculated according to the ratio: $\mathrm{Rf}=\mathrm{Pf} / \mathrm{Pi}$. This experiment was repeated twice. Five plants for scallion and 10 plants for rice genotype were used for each repeat. Plants with $\mathrm{Rf}<1$ were considered resistant, and $\mathrm{Rf}>1$ as susceptible (Soriano et al., 1999). The Rf of first repeat was present in the result.

\section{Statistical analyses for the reproductive factor and soil properties}

All statistical analyses were performed using R software ( $\mathrm{R}$ core Team, 2015). Two sample Student's t-tests were used to compare the different means in $\mathrm{Rf}$ of rice and scallion with 95 percent confidence interval. Variance analysis was used to compare the three fields for the different parameters of soil properties using the Kruskal Wallis test.

\section{RESULTS}

\section{Soil characteristics}

Measured $\mathrm{pH}\left(\mathrm{pH} \mathrm{H}_{2} \mathrm{O}\right.$ and $\left.\mathrm{pH} \mathrm{KCl}\right)$ as well as chemical contents, including organic carbon (OC), organic matter (OM), nitrogen $(\mathrm{N})$, sulfur (S) and cation exchange capacity (CEC), were in a range suitable for rice growing (McCall 1980; Dwevedi et al., 2017; Mccauley et al., 2017). No significant differences were observed for each parameter in the four repeats of each field and among the three fields $(p>0.05)$. The average of the four repeats in each field for each property is summarized in table 1 . Only phosphorous (P), measured by $\mathrm{P}_{2} \mathrm{O}_{5}$ 
$(\%)$, were present in a relatively high level in the three prospected fields. With a $\mathrm{pH}$ below 6.5 , phosphorus uptake by the plant is optimum and therefore the field did not need any more chemical $\mathrm{P}$ input (Pagliari et al., 2017).

Table 1. Physical and chemical properties of soil in Nam Sach, Hai Duong

\begin{tabular}{|c|c|c|c|c|c|c|c|c|c|c|c|c|}
\hline \multirow{2}{*}{ Field } & \multirow{2}{*}{$\begin{array}{c}\mathrm{pH} \\
\mathrm{H}_{2} \mathrm{O}\end{array}$} & \multirow{2}{*}{$\begin{array}{l}\mathrm{pH} \\
\mathrm{KCl}\end{array}$} & \multicolumn{5}{|c|}{ Total content } & \multirow{2}{*}{$\begin{array}{l}\text { Avail. } \\
\mathrm{SO}^{2-} \\
(\mathrm{mg} / 100 \\
\mathrm{g})\end{array}$} & \multirow{2}{*}{$\begin{array}{c}\text { CEC } \\
(\mathrm{meq} / 100 \\
\mathrm{g})\end{array}$} & $\begin{array}{c}<0.002 \\
\mathrm{~mm}\end{array}$ & $\begin{array}{c}0.002- \\
0.02 \mathrm{~mm}\end{array}$ & $\begin{array}{c}0.02-2 \\
\mathrm{~mm}\end{array}$ \\
\hline & & & $\begin{array}{l}\mathrm{OC} \\
(\%)\end{array}$ & $\begin{array}{l}\text { OM } \\
(\%)\end{array}$ & $\begin{array}{c}\mathrm{N} \\
(\%)\end{array}$ & $\begin{array}{c}\mathrm{P}_{2} \mathrm{O}_{5} \\
(\%)\end{array}$ & $\begin{array}{c}\mathrm{S} \\
(\%)\end{array}$ & & & \multicolumn{3}{|c|}{$\%$} \\
\hline 1 & $6.33^{\mathrm{a}}$ & $5.68^{\mathrm{a}}$ & $1.63^{\mathrm{a}}$ & $2.81^{\mathrm{a}}$ & $0.15^{\mathrm{a}}$ & $0.29^{\mathrm{a}}$ & $0.02^{\mathrm{a}}$ & $30.36^{\mathrm{a}}$ & $13.15^{\mathrm{a}}$ & $20.9^{\mathrm{a}}$ & $43.2^{\mathrm{a}}$ & $35.9^{\mathrm{a}}$ \\
\hline 2 & $6.23^{\mathrm{a}}$ & $5.75^{\mathrm{a}}$ & $1.47^{\mathrm{a}}$ & $2.53^{\mathrm{a}}$ & $0.15^{\mathrm{a}}$ & $0.26^{\mathrm{a}}$ & $0.02^{\mathrm{a}}$ & $39.64^{\mathrm{a}}$ & $12.65^{\mathrm{a}}$ & $20.4^{\mathrm{a}}$ & $42.6^{\mathrm{a}}$ & $37.0^{\mathrm{a}}$ \\
\hline 3 & $6.18^{\mathrm{a}}$ & $5.70^{\mathrm{a}}$ & $1.54^{\mathrm{a}}$ & $2.65^{\mathrm{a}}$ & $0.15^{\mathrm{a}}$ & $0.27^{\mathrm{a}}$ & $0.02^{\mathrm{a}}$ & $43.21^{\mathrm{a}}$ & $13.28^{\mathrm{a}}$ & $22.7^{\mathrm{a}}$ & $42.4^{\mathrm{a}}$ & $35.0^{\mathrm{a}}$ \\
\hline
\end{tabular}

Note: Column numbers followed by the same letter $\left({ }^{\text {a }}\right)$ are not significantly different at $P=0.05$ as determined by Kruskal-Wallis test.

Comparison of the soil texture with the 12 major textural classes and particle size scale (Malla, 2017) revealed that the three fields in Hai Duong Province were characterized by a loamy soil which is appropriate for growing most plant varieties including rice and scallion (Brown, 2007).

\section{Morphology characters and molecular identification}

Morphological characters of $M$. gramminicola Golden \& Birchfield fit descriptions by Hirschmann (1985), Nguyen \& Nguyen (2000) and Perry at al. (2009). Females with pearly white body, small neck, body length $(\mathrm{L}=570.09 \pm 54.11 \mu \mathrm{m})$ (Fig. 2A). Lip region smooth, anteriorly flattened, not distinctly set off from neck
(Fig. 2B). Rounded stylet knobs with posteriorly sloping anterior margins, $11.03 \pm$ $1.1 \mu \mathrm{m}$ long (Fig. 2B). Excretory-secretory pore very distinct, generally located about one and one-half-stylet lengths or more from base of unprotruded stylet (Fig. 2B). Perineal pattern prominent with distinct and characteristic striations (Fig. 2C). The J2 character by body cylindrical vermiform, tapering markedly toward posterior end $(\mathrm{L}=$ $464.57 \pm 42 \mu \mathrm{m}$ ). Stylet slender; knobs small, oval-shaped and backwardly sloping, stylet length $(11.07 \pm 0.69 \mu \mathrm{m})$. Lip region flat anteriorly, continuous with body, and weakly sclerotized (Fig. 2D); 0Tail shape and tail terminus rounded, often slightly clavate with tail length $(68.84 \pm 5.77 \mu \mathrm{m})$, hyaline tail length $(20.20 \pm 2.87 \mu \mathrm{m})$ (Fig. 2E).
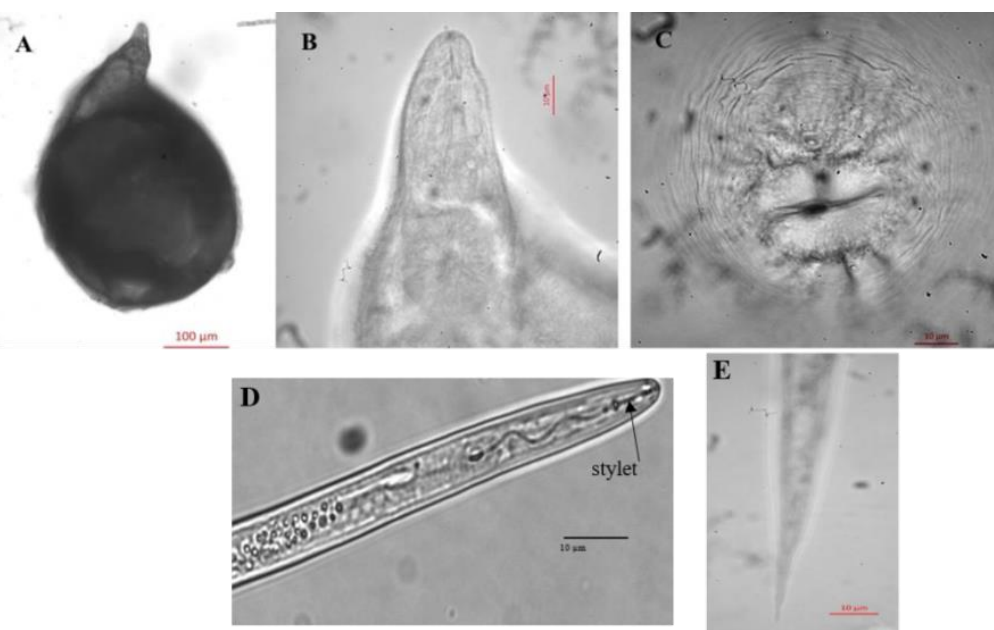

Figure 2. Morphological character of M. graminicola females from Hai Duong. A: Entire body, B: Head region, C: Perineal pattern, D: Anterior end of juvenile stage 2, E: Juvenile tail tip 
500 base pair (bp.) in the ITS region of Hai Duong PPN was amplified by PCR and sequenced. Comparison of the amplified sequences with other available sequences using Nucleotide Basic Local Alignment Search Tool (BLASTN) (http://blast.ncbi.nlm.nih.gov/) revealed that among the seven PPN sequenced, all were M. graminicola with a high level of similarity from $99.67 \%$ to $100 \%$. Sequence alignment against reference $M$. graminicola populations (MgVN18 KF250488) did not present intraspecific variation. The sequenced rDNA region was identical to that of M. graminicola VN13 (accession number
KF250481) a population previously isolated from the same region (Bellafiore et al., 2015). The phylogenetic trees showed that the seven Hai Duong Meloidogyne isolates were in the same clade as the three reference M. graminicola (KF250488, KF250481 and HM623442). In this tree, the closest but significantly distant RKN species is $M$. naasi (JN157863) and the RKN isolated from Hai Duong are more distant from Meloidogyne hapla LC030362.1 LC030359.1; Meloidogyne javanica (AY438555), Meloidogyne incognita (KC464469) and Meloidogyne arenaria (AF387092) (Fig. 3).

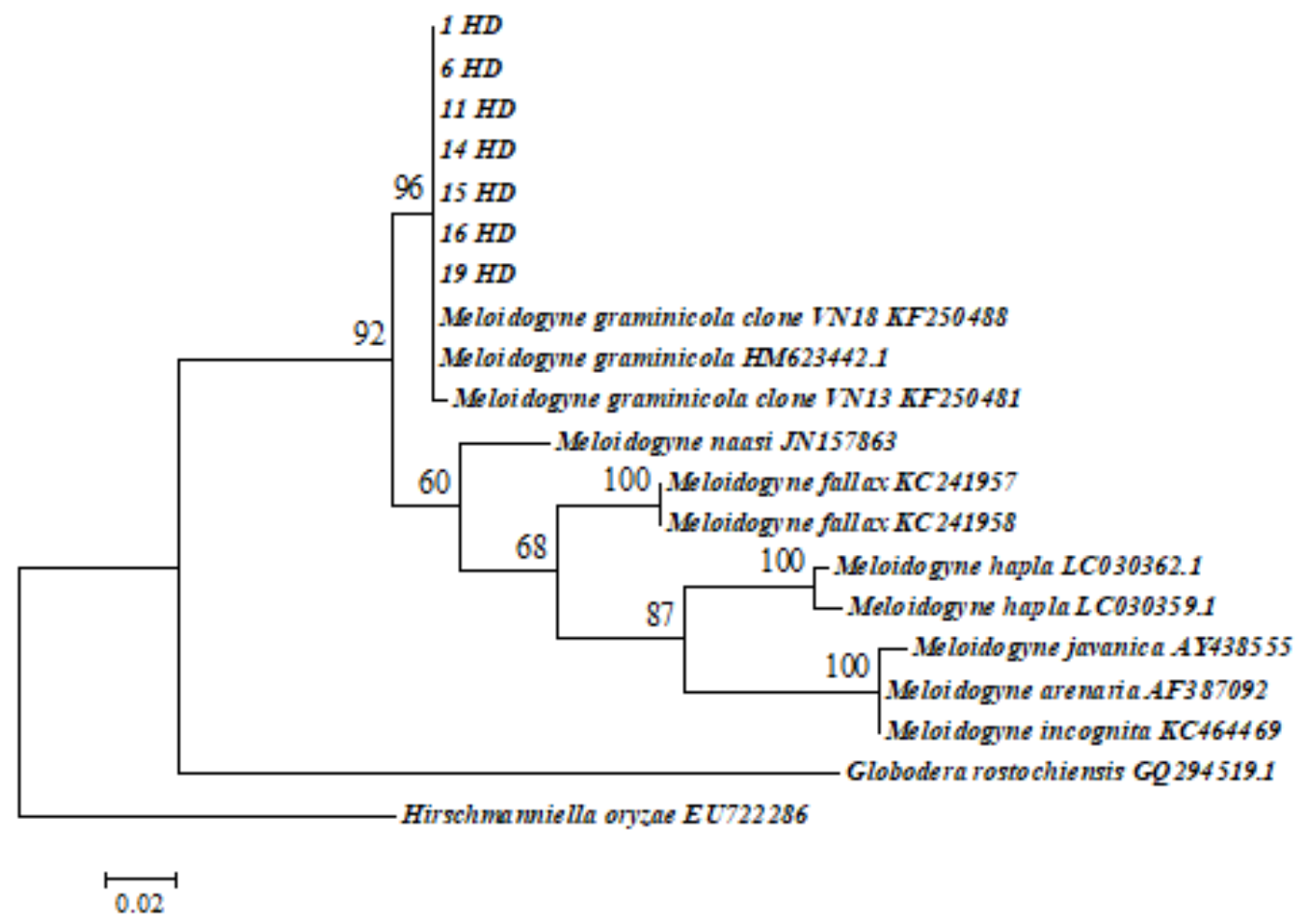

Figure 3. Evolutionary relationships of ITS sequences are estimated using maximum-likelihood. Branches with bootstrap support $>70 \%$ are indicated (1000 replications). The scale bar denotes 0.02 substitutions per nucleotide position. All positions containing gaps and missing data were eliminated. (1 HD, $6 \mathrm{HD}, 11 \mathrm{HD}, 14 \mathrm{HD}, 15 \mathrm{HD}, 16 \mathrm{HD}, 19 \mathrm{HD}$ : the sequence of Meloidogyne collected in Hai Duong rice field)

Reproduction and pathogenicity of $\boldsymbol{M}$. remained on the edges of the fields. graminicola

Therefore, the susceptibility to $M$. graminicola of the scallion used during the

At the time of the survey, only rice was crop rotation in winter was tested under cultivated and some unplanted scallion bulbs controlled conditions in a grow chamber. 
After 27 dpi, small galls were easily identified in the root system (Fig. 4B). Acid fuchsin staining confirmed the susceptibility of scallion and rice varieties cultivated by farmers in this field (Figs. 4A, 4B). $M$. graminicola eggs and females were present in abundance in the roots of the scallion plants (Fig. 4C).
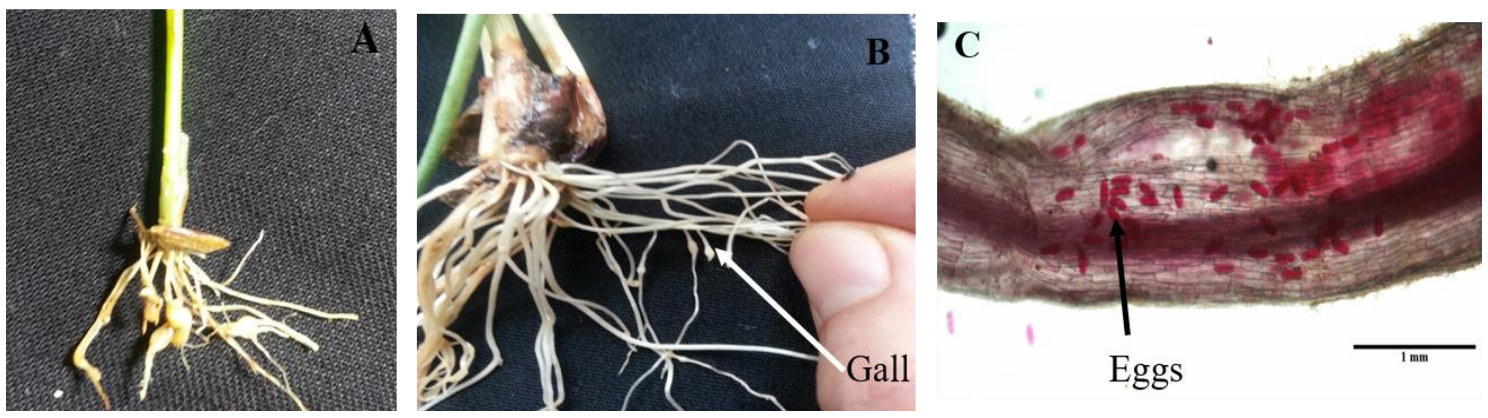

Figure 4. A: The typical root galls of Bac Thom rice variety in M. graminicola infested field. B: The terminal root galls of scallion bulbs after inoculated with M. graminicola. C: The eggs of M. graminicola (arrow) are released by the female directly in the root of scallion bulbs

After $27 \mathrm{dpi}$, the measurement of $\mathrm{Rf}$ revealed significant differences between IR64 and scallion plants (p-value $<0.001)$ with the Rf value in IR64 (19.25) being five times higher than that in scallions (3.96) (Fig. 4). Therefore, the varieties of rice and scallion used by farmers are susceptible to infection with M. graminicola.

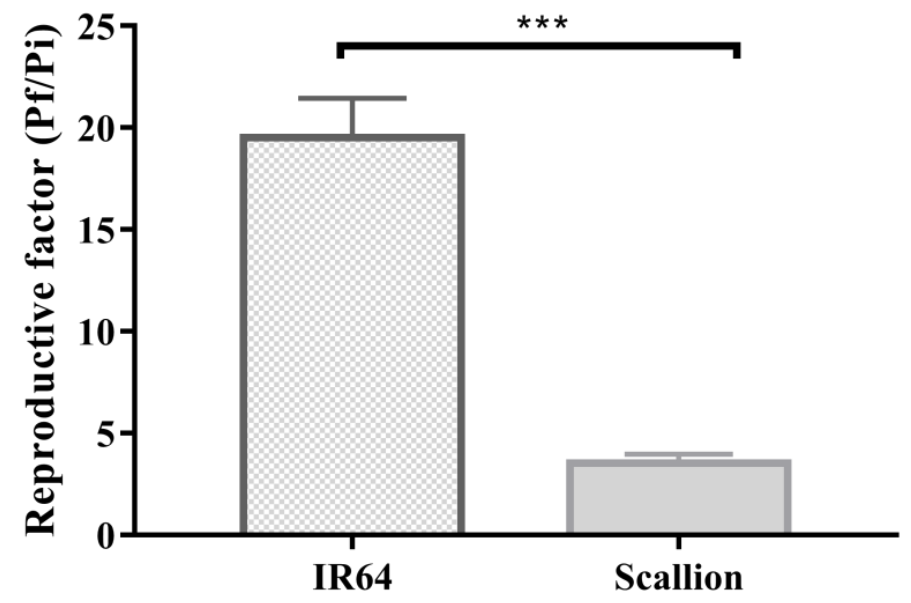

Figure 5. Reproduction factors of M. graminicola on O. sativa cv. IR64 and local scallion cv. The graph shows the average values of reproductive factor of scallion and IR64 in two repeat. The number of replicated plants is $n=5$ for scallion and $n=10$ for rice

\section{DISCUSSION}

Based on morphological observations and DNA barcoding, we showed that the 10 ha of the farm inspected in Hai Duong Province were severely infected with PPN, $M$. graminicola. This globally distributed species has become a serious pest in several tropical countries in Asia and notably in Vietnam in deep water and irrigated systems (Cuc \& Prot, 1992; Cuc \& Prot, 1995, Bridge et al., 2005; Bellafiore et al., 2015; Jain et al., 2012; Davide, 1988; Mantelin et al., 2017). However, to our knowledge, this is the first time that this species causes a massive 
infection in the country leading to almost $100 \%$ plant damage in a 10 ha field. Usually, $M$. graminicola infection in a field is limited to several small areas and the infection can be revealed by patch formation in the field where the plants are chlorotic and show a delay in their development (Mantelin et al., 2017). We therefore investigated the reasons that could explain this preliminary observation where $M$. graminicola could potentially devastate rice agriculture and farmer economy.

In the field, we systematically noticed that all plants with abnormal development were infected by PPN, which suggested that the selected varieties were highly susceptible to $M$. graminicola under natural growing conditions. In order to assess the aggressiveness of this specific Hai Duong M. graminicola population, we tested the infectivity of this population against IR64, an Oryza sativa indica species known to be a good host for M. graminicola (Soriano et al., 1999) and routinely used to study rice-nematode interactions. The aggressiveness of the Hai Duong $M$. graminicola on IR64 was similar to the results observed with other populations collected in Vietnam and in other countries. For instance, in Vietnam, 20 M. graminicola populations have been collected in 10 sites from different rice growing regions. After two life cycles, all Vietnamese $M$. graminicola populations were highly reproductive on rice cv. IR64 with a $\mathrm{Rf}$ value ranging from 11 to 19 (Bellafiore et al., 2015), similar to the isolate collected in Hai Duong ( $\operatorname{Rf}$ of 19.25). This suggests that the high level of $M$. graminicola infection as observed in prospected Hai Duong fields is not due to the emergence/selection of a more aggressive host pathogen with a superior fitness but rather the plants becoming more susceptible to the infection due to exceptional agro-ecosystem conditions.

Physical changes in the soil are known to affect nematode behaviors (Oka Y., 2010). We analyzed the soil physical and chemical properties of the infested fields but only the content of $\mathrm{P}$ was relatively high and all the other parameters were in an optimum range for rice production. The high $\mathrm{P}$ value could be due to massive use of phosphorus fertilizers by farmers for intensive rice and scallion production. There are three main form of phosphorous in the soil: active $\mathrm{P}$, fixed $\mathrm{P}$ and soluble P. Plants will firstly uptake soluble P which contains a mix of inorganic $P$ and organic $\mathrm{P}$ with inorganic $\mathrm{P}$ being the major type, followed by active and fixed P (Pagliari et al., 2017; Nishigaki et al., 2019). Continuous addition of more $\mathrm{P}$ in the soil could increase more fertility in the soil but $\mathrm{P}$ could also be fixed and become unavailable (Pagliari et al., 2017), resulting in environmental pollution (Choudhury et al., 2007). However, high levels of phosphate will not negatively impact the crops and no correlation between $\mathrm{P}$ abundance and nematode infection has been previously reported. Therefore, the physical and chemical properties did not reflect any major characteristic that could explain the abundance of $M$. graminicola.

We, therefore, investigated if farmers applied a specific agricultural practice that could explain the high infection level. In Asia, farmers mainly use wet direct seeding method to cultivate rice by broadcasting or drilling into drained, well-puddled seedbeds or into shallow standing water (Balasubramanian et al., 2002) in which the two first seedbed types might be convenient conditions for $M$. graminicola infectivity. Indeed, this nematode can quickly invade the young rice roots when infested soils are drained (Manser, 1968). Direct seeding methods have many benefits such as reduction of labor work but also have side effects, such as promoting weed development and in some conditions, disease and pest infections (Farooq et al., 2011). According to Farooq et al. (2011), grain yields in direct seeding field were lower than this in transplanting field, whereas others reported that the rice yields of direct seeding under good management control was equal to, or even higher than those of transplanted rice (Huang et al., 2011; Liu et al., 2015). Because $M$. graminicola has a wide range of hosts which include many common weeds in the rice field, direct seeding methods could create 
favorable conditions for $M$. graminicola proliferation on the weeds which continue to infect rice in the next season (De Waele \& Elsen, 2007; MacGowan \& Landon, 1989). In the prospected area of the Hai Duong Province, several farmers modified their agricultural practices from traditional transplanting to direct seeding method. We observed that the farmers that had shifted to the direct seeding method suffered severe damage due to a massive $M$. graminicola infection.

Finally, we showed that the scallion used by farmers in the crop rotation sequence was a variety susceptible to $M$. graminicola. Consequently, it helped maintain a significant $M$. graminicola population in the soil during the winter season before planting rice. Scallion was previously reported as a good host of M. graminicola. The growth and yields of the Yellow Granex scallion variety grown in a cropping sequence with rice in the Philippines, was severely reduced due to $M$. graminicola infection (Gergon et al., 2002). Therefore, M. graminicola infection is not only reducing the expected income from rice cultivation but also from scallion. Although crop rotation is an important practice that can help farmers to limit nematode occurrence in a field (Mantelin et al., 2017, Védie et al., 2014), a wrong combination of plants can have the opposite effect of contributing to the proliferation of the pest followed by severe damage to the cultivated plants. A solution for the farmers should be using resistant rice varieties (Dimkpa et al., 2016; Thi Phan et al., 2017) and/or to grow non-susceptible plants instead of scallion. If the same cropping system persisted and no nematode control strategies were implemented, a strongly increasing number of $M$. graminicola would be expected in the field year by year.

In order to reduce the negative impact of this pest on rice production, it is critical to increase the farmer's awareness on the risk of plant parasitic nematode infection as too many severe nematode infections on rice are being mis-identified. Indeed, due to limited root development caused by the nematode infection, parasitized plants can present the same leaf symptoms as nutrient starvation and water stress. The infected plants can also present other sickness symptoms that are originally due to $M$. graminicola, as this nematode causes its host to be more susceptible to other pathogens (Kyndt et al., 2017). Fortunately, symptoms of infected roots are easily identifiable and farmers can quickly be aware of the presence of $M$. graminicola when they inspect carefully the rice root system.

\section{CONCLUSION}

The RKN found in Hai Duong fields were morphologically and molecularly identified as $M$. graminicola-a serious pathogenic species in rice. For the first time in Vietnam, our experiment showed that $M$. graminicola could parasitize and propagate in scallions of Vietnam although this plant is annually cultivated on a paddy field for crop rotation. A combination of three factors (wrong crop choice for rotation, rice variety susceptible to M. graminicola and direct seeding) obviously favored the nematode infection and its high proliferation in the surveyed fields. The results of this study suggested some recommendations: 1 . Using a crop rotation system with at least one plant not susceptible to $M$. graminicola. If planting two susceptible crops (e.g. scallion and rice) is vital for the farmers, then a precise water management system is required to flood the field to limit the nematode infection. 2. Using rice varieties less or not susceptible to nematode infection. If no specific nematode control is planned (soil solarization, use of resistant cultivars...), avoid direct seeding and irrigation delay as both are favorable to $M$. graminicola infection. We recommend transplanting young rice plants from a non-infected nursery in a flooded field. Under flooding conditions, RKN like $M$. graminicola are unable to penetrate the root system and cause significant rice yield loss.

\section{REFERENCES}

Balasubramanian V., Hill J. E., 2002. Direct seeding of rice in Asia: emerging issues 
and strategic research needs for the $21^{\text {st }}$ century. Proceedings of the international workshop on direct seeding in Asian rice systems: Strategic research issues and opportunities, 2: 15-34.

Bellafiore S., Jougla C., Chapuis É., Besnard G., Suong M., Vu P. N., De Waele D., Gantet P., Thi X. N., 2015. Intraspecific variability of the facultative meiotic parthenogenetic root-knot nematode (Meloidogyne graminicola) from rice fields in Vietnam. Comptes RendusBiologies, 338(7): 471-483.

Bridge J., Page S. L., 1982. The rice rootknot nematode, Meloidogyne graminicola, on deep water rice (Oryza sativa subsp. indica). Revue de Nématologie, 5: 225-232.

Bridge J., Plowright R. A., Peng D., 2005. Nematode parasites of rice. In: Luc, M., Sikora, R. A. and Bridge, J., (ed) Plant parasitic nematodes in subtropical and tropical agriculture. Wallingford UK: CABI Bioscience: 87-130.

Brown R. B., 2007. Soil texture. Agronomy fact sheet series: fact sheet SL-29. Department of crop and soil sciences, Cornell University, pp. 1-8.

Byrd D. W. J., Kirkpatrick T., Barker K. R., 1983. An improved technique for clearing and staining tissues for detection of nematodes. Journal of Nematology, 15: 142-143.

Castresana J., 2000. Selection of conserved blocks from multiple alignments for their use in phylogenetic analysis. Mol. Biol. Evol. 17: 540-552.

Choudhury A. T. M. A., Kennedy I. R., Ahmed M. F., Kecskes M. L., 2007. Phosphorus fertilization for rice and control of environmental pollution problems. Pakistan Journal of Biological Sciences, 10: 2098-2105.

Cuc N. T. T., Prot J. C., 1992. Root-Parasitic Nematodes of deep-water rice in the Mekong delta of Vietnam. Fundam. Apply Nematol., 15(6): 575-577.
Cuc T. T., Prot J. C., 1995. Nematode parasites of deepwater and irrigated rice in the Mekong River Delta. Vietnam and IRRI: A Partnership in Rice Research: 251-260.

Davide R. G., 1988. Nematode problems affecting agriculture in the Philippines. Journal of Nematology, 20(2): 214-218.

De Waele D., Elsen A., 2007. Challenges in tropical plant nematology. Annual Review of Phytopathology, 45(1): 457-485.

Dimkpa S. O., Lahari Z., Shrestha R., Douglas A., Gheysen G., Price A. H., 2016. A genome-wide association study of a global rice panel reveals resistance in Oryza sativa to root-knot nematodes. Journal of Experimental Botany, 67(4): 1191-1200.

Dwevedi A., Kumar P., Kumar Y., Sharma Y. K., Kayastha A. M., 2017. Soil sensors: detailed insight into research updates, significance, and future prospects. New Pesticides and Soil Sensors, 561-594. Doi:10.1016/b978-0-12-804299-1.00016-3.

Edgar R. C., 2004 MUSCLE: multiple sequence alignment with high accuracy and high throughput. Nucleic Acids Res., 32: 1792-1797.

FAO, 2017. FAOSTAT. Food and Agriculture Organization of the United Nations, Rome, Italy.

Farooq M., Siddique K. H. M., Rehman H., Aziz T., Lee D. J., Wahid A., 2011. Rice direct seeding: Experiences, challenges and opportunities. Soil and Tillage Research, 111(2): 87-98.

Gergon E. B., Miller S. A., Halbrendt J. M., Davide R. G., 2002. Effect of rice rootknot nematode on growth and yield of Yellow Granex scallion. Plant Disease, 86(12): 1339-1344.

Hartman K. M., Sasser J. N., 1985. Identification of Meloidogyne species by differential host test and perineal pattern morphology. In K. R. Barker, C. C. Carter, and J. N. Sasser (Eds). An advanced treatise on Meloidogyne; Vol. II: 
Methodology. North Carolina State University Graphics, Raleigh. pp. 69-77.

Hirschmann H., 1985. The genus Meloidogyne and morphological characters differentiating its species. In: Sasser JN, Carter CC, (ed) An Advanced Treastise on Meloidogyne Volume I, Biology and Control. Raleigh, NC: North Carolina State University: 79-93.

Huang M., Zou Y., Jiang P., Xia B., Feng Y., Cheng Z. \& Mo Y., 2011. Yield component differences between direct-deeded and transplanted super hybrid rice, Plant Production Science, 14(4): 331-338.

Jain R. K., Khan M. R., Kumar V., 2012. Rice root-knot nematode (Meloidogyne graminicola) infestation in rice. Archives of Phytopathology and Plant Protection, 45(6): 635-645.

Kyndt T., Zemene H. Y., Haeck A., Singh R., De Vleesschauwer D., Denil S., 2017. Belowground attack by the root knot nematode Meloidogyne graminicola predisposes rice to blast disease. Mol. Plant Microbe Interact, 30: 255-266.

Liu H., Hussain S., Zheng M., Peng S., Huang J., Cui K., Nei L., 2015. Dry direct seeded rice as an alternative to transplantedflooded rice in Central China. Agron. Sustain. Dev. 35: 285-294.

Luu T. N. M., Garnier J., Billen G., Le T. P. Q., Nemery J., Orange D., Le L. A., 2012. $\mathrm{N}, \mathrm{P}, \mathrm{Si}$ budgets for the Red River Delta (northern Vietnam): How the delta affects river nutrient delivery to the sea. Biogeochemistry, 107(1-3): 241-259.

MacGowan J. B., Langdon K. R., 1989. Hosts of the rice root-knot nematode, Meloidogyne graminicola. Nematol. Circ. Gainesville, 172.

Malla S. Y., 2017. What is the soil texture In T. U.H. Malik and S. T. Hussain (Eds). The ABCs of agriculture science (pp: 65-70). Retrieved from https://books.google.com.

Manser P. D., 1968. Meloidogyne graminicola a cause of root knot of rice. FAO Plant Protection Bulletin 16, 11.
Mantelin S., Bellafiore S., Kyndt T., 2017. Meloidogyne graminicola a major threat to rice agriculture. Molecular Plant Pathology, 18: 3-15.

McClure M. A., Kruk T. H., Misaghi I., 1973. A method for obtaining quantities of clean Meloidogyne eggs. Journal of Nematology 5(3): 230.

McCauley A., Jones C., Olson-Rutz K., 2017. Soil $\mathrm{pH}$ and Organic Matter. Nutrient Management Module No 8 (pp. 1-16). Montana State University.

McCall W. M., 1980. The $\mathrm{pH}$ preference of plants. General home garden series, (18): 6-7.

Nicol J. M., Turner S. J., Coyne D. L., den Nijs L., Hockland S., Maafi Z. T., 2011. Current nematode threats to world agriculture. Genomics and Molecular Genetics of Plant-Nematode Interactions: 21-44.

Nguyen N. C., Nguyen V. T., 2000: Plant parasitic nematodes in Vietnam. The Fauna of Vietnam Volume 4. Hanoi, Vietnam, Science and Technology Pub., 400 pp. (in Vietnamese).

Nguyen T. D., 2009. Vietnam responds to climate change. Available at http://www.davifo.dk/userfiles/file/pdf/Vie tnam_Climate_20091120_COP15.pdf Accessed in January 2010.

Nishigaki T., Tsujimoto Y., Rinasoa S., Andriamananjara A., Razafimbelo T., 2019. Phosphorus uptake of rice plants is affected by phosphorus form and physicochemical properties of tropical weathered soil. Plant soil, 435: 27.

Oka Y., 2010. Mechanisms of nematode suppression by organic soil amendments A review. Applied Soil Ecology, 44(2): 101-115.

Pagliari P. H., Kaiser D. E., Rosen C. J., Lamb J. A., 2017. The nature of phosphorus in soils. Nutrient Management. Retrieved from http://books.google.com.

Perry R., Moens M., 2013. Plant nematology. 2nd (ed) Wallingford, UK, CABI, pp. 568. 
Pham Thi Thu Huong, Everaarts A. P., Neeteson J. J., Struik P. C., 2013. Vegetable production in the Red. I. Opportunities and constraints. NJASWageningen Journal of Life Sciences. 67: 27- 36.

Prot J. C., Matias D. M., 1995. Effects of water regime on the distribution of Meloidogyne graminicola and other rootparasitic nematode in rice field toposequence and pathogenicity of $M$. graminicola on rice cultivar UPL R15. Nematologica, 41: 219-228.

R Core Team. 2015. R: A language and environment for statistical computing. $\mathrm{R}$ Foundation for Statistical Computing, Vienna, available at: www.R-project.org/.

Seinhorst J. W., 1959. A rapid method for the transfer of nematodes from fixative to anhydrous glycerin. Nematologica 4: 67-69.

Soriano I. R., Schmit V., Brar D. S., Prot J. C., Reversat G., 1999. Resistance to rice root-knot nematode Meloidogyne graminicola identified in Oryza longistaminata and $O$. glaberrima. Nematology, 1(4): 395-398.

Thi Phan N., De Waele D., Lorieux M., Xiong L., Bellafiore S., 2017. A Hypersensitivity-Like Response to Meloidogyne graminicola in rice (Oryza sativa L.). Phytopathology. 108(4): 521-528.

Vrain T. C., Wakarchuk D. A., Levesque A. C., Hamilton R. I., 1992. Intraspecific rDNA restriction-fragment-lengthpolymorphism in the Xiphinemaamericanum group. Fundam. Appl. Nematol., 15: 563-573.

Védie H., Mateille T., Tavoillot J., 2014. Soil solarization and crop rotation to manage root-knot nematodes in organic greenhouse. Acta Hortic. 1041: 87-94.

World Bank. 2019. Data. http://data.worlbank.org/indicator. 